\title{
UJI VALIDITAS PENGEMBANGAN TES UNTUK MENGUKUR KEMAMPUAN PEMAHAMAN RELASIONAL PADA MATERI PERSAMAAN KUADRAT SISWA KELAS VIII SMP
}

\author{
${ }^{1}$ Rizki Riyani, ${ }^{2}$ Syafdi Maizora, ${ }^{3}$ Hanifah \\ ${ }^{1,2,3}$ Program Studi Pendidikan Matematika FKIP Universitas Bengkulu

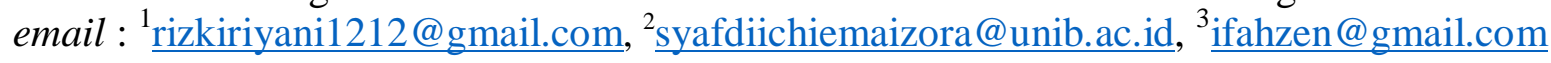

\begin{abstract}
Abstrak
Penelitian ini bertujuan untuk mengetahui kevalidan pengembangan tes untuk mengukur kemampuan relasional. Penelitian ini dilatar belakangi oleh soal tes yang biasa diberikan oleh guru belum memuat perhitungan secara prosedural, dan masih kurang bervariasi. Dengan pemahaman relasional siswa mampu menerapkan rumus secara bermakna dan disertai alasan, mengkaitkan satu idea dengan idea lain, dan membuktikan kebenaran suatu rumus. Jenis penelitian pengembangan (Research and Development) dengan mengadopsi prosedur pengembangan 4-D. Penelitian dilakukan tiga tahap yaitu: Define, Design, dan Develop. Instrumen penelitian yang digunakan adalah lembar validasi. Subjek penelitian ini adalah siswa kelas VIII F, VIII H, dan VIII I SMP Negeri 1 Kepahiang. Hasil penelitian menunjukkan bahwa tes yang dikembangkan dikategorikan valid serta tes dapat digunakan.
\end{abstract}

Kata Kunci: kemampuan pemahaman relasional, penelitian pengembangan, persamaan kuadrat

\begin{abstract}
The purpose of this study is to know the validity of test development to measure relational understanding. This research was conducted because of the test given by the teacher usually did not contain procedural calculation, and it also still less variation. With relational understanding students are able to apply formulas meaningfully and accompanied by reason, associate one idea with another idea, and prove the trutj of a formula. Type of this study is Reseach and Development by adopting 4-D development procedures. The instruments of this study were validation sheets. The subject of this study were class students graders VIII F, VIII H and VIII I Public junior high school number 1 Kepahiang. The result shows that developing test is categorized as valid as well as test can be used.
\end{abstract}

Keywords: measure relational understanding, research and development, quadratic equation

\section{PENDAHULUAN}

Mempelajari matematika sangat penting demi mencapai tujuan pembelajaran matematika, salah satu tujuan pembelajaran matematika adalah meningkatkan kemampuan matematis. Menurut Hendriana dan Soemarmo (2014: 19) berdasarkan jenisnya, kemampuan matematis dapat diklasifikasikan dalam lima kompetensi utama yaitu: pemahaman matematik (mathematical undersanding), pemecahan masalah (mathematical problem solving), komunikasi matematik (mathematical communication), koneksi matematik (mathematical connection), danpenalaran matematik (mathematical reasoning).

Untuk mengetahui pemahaman matematis siswa, diperlukan pengukuran kemampuan pemahamannya. Sehingga demikian guru dapat melihat kemampuan pemahaman matematis siswa tersebut. Salah satu teknik penilaian dalam evaluasi pembelajaran adalah tes. Menurut Mardapi (2008: 67) tes merupakan salah satu cara untuk menaksir besarnya tingkat kemampuan manusia secara tidak langsung, yaitu melalui respon seseorang terhadap sejumlah stimulus atau pertanyaan. Skemp (Sumarmo dalam Hendriana dan soemarmo 
,2014: 20) menggolongkan pemahaman dalam dua tingkat (1) Pemahaman instrumental: hafal konsep/prinsip tanpa kaitan dengan yang lainnya, dapat menerapkan rumus dalam perhitungan sederhana, dan mengerjakan perhitungan secara algoritmik. Kemampuan ini tergolong pada kemampuan tingkat rendah. (2) Pemahaman relasional: mengaitkan satu konsep/prinsip dengan konsep/prinsip lainnya. Kemampuan ini tergolong pada kemampuan tingkat tinggi.

Pemahaman tingkat tinggi/relasional ini sering kali diabaikan oleh guru di sekolah karena untuk mengetahui pemahaman tingkat tinggi guru dituntun memberikan soal tes yang lebih kreatif. Pemahaman tingkat tinggi/relasional pada diri siswa perlu dibentuk dan lebih dikembangkan di sekolah.

Berdasarkan hasil observasi penulis yang dilaksanakan tanggal 31 Januari 2017 di SMPN 01 Kabupaten Kepahiang diperoleh beberapa temuan. Guru terbiasa memberikan soal tes yang kurang memacu siswa untuk mengetahui materi secara prosedural sehingga siswa hanya terbiasa mengerjakan soal yang dapat dikategorikan soal pemahaman tingkat rendah.

Kelebihan mengukur kemampuan pemahaman relasional siswa adalah guru dapat mengetahui sebatas mana kemampuan pemahaman siswa secara konseptual dan prosedural sehingga dapat diketahui bahwa siswa telah memahami materi yang telah diberikan secara utuh dan benar sesuai dengan tujuan pembelajaran matematika.

Menurut Polya dalam Sumarmo (2013: 4) pemahaman relasional yaitu dapat menerapkan rumus secara bermakna dan disertai alasan, mengkaitkan satu idea dengan idea lain, dan membuktikan kebenaran suatu rumus.

Skemp (2002: 9-11) menyatakan bahwa There are four advantages (at least) in relational mathematics. (1) It is more adaptable to new tasks. (2) It is easier to remember. (3) Relational knowledge can be effective as a goal in itself. (4) Relational schemas are organic in quality.

Pemahaman relasional sifat pemakaiannya lebih bermakna, termuat suatu skema atau struktur yang dapat digunakan untuk menyelesaikan masalah yang lebih luas. Siswa yang berusaha memahami secara relasional akan mencoba mengaitkan konsep baru dengan konsep-konsep yang dipahami untuk dikaitkan dan kemudian merefleksi keserupaan dan perbedaan antara konsep baru dengan pemahaman sebelumnya.

Adapun indikator soal pemahaman relasional yaitu:

1. Soal menanyakan tentang rumus secara bermakna dan disertai alasan

2. Soal berkaitan antara satu konsep dengan konsep lain

3. Soal memuat pembuktian kebenaran suatu rumus.

(Skemp,2002).

Jadi, dapat dikatakan pemahaman tingkat tinggi/relasional adalah kemampuan seseorang menggunakan suatu prosedur matematis untuk menyelesaikan suatu masalah dengan mengetahui prosedur kegunaan penyelesaian masalah tersebut atau dapat dikatakan seseorang tersebut paham materi secara konseptual dan prosedural. Apabila tidak termasuk pemahanan instrumental pasti termasuk pemahaman relasional.

Diadaptasi dari Nieven dalam Prastowo (2013: 32) menyatakan bahwa aspek validitas terkait dengan dua hal, yaitu apakah produk yang dikembangkan didasarkan pada rasional teoritis yang kuat dan apakah terdapat konsistensi internal.

Berdasarkan uraian dari latar belakang di atas rumusan masalah yang akan dikaji dalam penelitian ini yaitu :

Bagaimana kevalidanhasil pengembangan tes untuk mengukur kemampuan pemahaman relasional pada materi persamaan kuadrat siswa kelas VIII SMP?

Adapun tujuan penelitian dan pengembangan ini adalah untuk:

Mengetahu kevalidan pengembangan tes untuk mengukur kemampuan pemahaman relasional pada materi persamaan kuadrat siswa kelas VIII SMP. 


\section{METODE}

Jenis penelitian yang digunakan dalam penelitian ini adalah penelitian dan pengembangan (Reseach and Development). Metode penelitian dan pengembangan adalah metode penelitian yang digunakan untuk menghasilkan produk tertentu dan menguji keefektifan produk tersebut. Produk yang dihasilkan dapat berupa produk yang baru ataupun menyempurnakan produk yang telah ada. Model pengembangan ini mengacu pada model prosedural yang bersifat deskriptif, menurut Trianto (2013: 190) langkah-langkah model pengembangan 4-D yaitu (1) Tahap Define atau Pendefinisian (2) Tahap Design atau Perencangan (3) Tahap Develop atau Pengembangan (4) Tahap Desseminate atau Penyebaran, karena hasil penelitian ini tidak disebarkan keinstansi atau lembaga lain selain tempat penelitian, maka tahap yang dilakukan hanya sampai tahap pengembangan.

Data evaluasi yang baik sesuai dengan kenyataan disebut data valid. Agar datanya valid maka harus menggunakan alat/instrumen yang valid. Instrumen ini digunakan untuk menentukan apakah suatu tes telah memiliki validitas atau ketepatan mengukur kemampuan pemahaman relasional.

Secara garis besar ada dua macam validitas, yaitu validitas logis dan validitas empiris. Validitas logis mengandung kata "logis" yang berarti penalaran. Jadi validitas logis akan melihat kevalidan berdasarkan hasil penalaran. Kondisi valid dipandang terpenuhi karena instrument sudah dirancang secara baik. Ada dua macam validitas logis yaitu validitas isi dan validitas konstrak (construct validity). Sedangkan "validitas empiris" memuat kata "empiris" yang artinya "pengalaman". Jadi sebuah instrument dikatakan valid dilihat dari pengalaman, instrument dikatakan memiliki validitas empiris apabila sudah diuji dari pengalaman.

Validitas logis yaitu kevalidan yang diuji oleh para ahli dan validitas empiris yaituk evalidan yang diuji kesiswa dan dilihat juga reliable, tingkat kesukaran dan daya pembedanya.

Teknik pengumpulan data yang digunakan dalam penelitian ini adalah pengumpulan data lembar validitas didapatkan dari validator ahli materi. Lembar validitas terdiri dari lembar validitas butir soal dan lembar validitas soal tes ahli materi. Lembar validitas akan diberikan ke para ahli ketika produk telah jadi, dan butuh divalidkan sebelum diuji ke siswa-siswa. Setelah valid secara logis, maka dilihat valid empirisnya yaitu validitas butir soal, reliabilitas soal, tingkat kesukaran soal, dan daya pembeda soal.

Teknik analisi data yang digunakan dalam penelitian ini adalah:

a. Analisis kevalidan butir soal

Validator akan melihat apakah soal sudah sesuai dengan kompetensi dasar dan indikator, apakah pokok soal sudah dirumuskan dengan singkat dan jelas. Jadi validator akan memberikan penilaian dengan memberikan tanda centang dari aspek tersebut tersebut terhadap butir soal tes. Dalam memvalidkan butir soal, validator memberikan penilaian/pendapat untuk validitasisi. Untuk validitas isi ada tiga pilihan penilaian, yaitu $\mathrm{V}=$ Valid, KV=Kurang Valid, dan TV=Tidak Valid.

b. Analisis kevalidan soal tes oleh ahli materi Validator soal tes ahli materi memberikan skor untuk setiap item dengan jawaban sangat sesuai (4), sesuai (3), cukup sesuai (2), kurang sesuai (1), dan tidak sesuai (0), selanjutnya menjumlahkan total skor tiap validator dan mencari rata-rata validitas dengan rumus

$$
V R=\frac{\sum_{i=1}^{n} \bar{V}_{l}}{n}
$$

Keterangan :

VR : rata-rata validitas

$\bar{V}_{l}$ : rata-rata skor tiap validator

$\mathrm{n}$ : banyak validator diadaptasi dari Sudjana (1995: 67)

Tabel 1 Kriteria Pengkategorian Validitas Soal oleh Ahli Materi

\begin{tabular}{|c|c|}
\hline Interval Skor & KategoriKevalidan \\
\hline $3 \leq \mathrm{VR} \leq 4$ & Sangat Valid \\
\hline
\end{tabular}




\begin{tabular}{|c|c|}
\hline $2 \leq \mathrm{VR}<3$ & Valid \\
$1 \leq \mathrm{VR}<2$ & Kurang Valid \\
$0 \leq \mathrm{VR}<1$ & Tidak Valid \\
\hline
\end{tabular}

c. Analisis validitas butir soal

Rumus yang digunakan yaitu:

$$
=\frac{\mathrm{N} \sum \mathrm{XY}-\left(\sum \mathrm{X}\right)\left(\sum \mathrm{Y}\right)}{\sqrt{\left\{\mathrm{N} \sum \mathrm{X}^{2}-\left(\sum \mathrm{X}^{2}\right)\right\}\left\{\mathrm{N} \sum \mathrm{Y}^{2}-\left(\sum \mathrm{Y}^{2}\right)\right\}}}
$$

Keterangan :

$\mathrm{r}_{\mathrm{xy}} \quad=$ koefisien korelasi yang dicari

$\mathrm{N}$ = banyaknya peserta tes

$\mathrm{X}=$ nilai variabel $\mathrm{X}$ (skor item)

$\mathrm{Y} \quad=$ nilai variabel $\mathrm{Y}$ (skor item)

Jika $r_{\text {hitung }}>r_{\text {tabel }}$ maka butir item valid.

d. Analisis reliabilitas soal

Untuk mengukur reliabilitas tes berupa soal uraian digunakan rumus Alpha yaitu :

$$
r_{11}=\left(\frac{k}{k-1}\right)\left(1-\frac{\sum \sigma_{b}{ }^{2}}{\sigma_{t}{ }^{2}}\right)
$$

Keterangan :

$\mathrm{r}_{11}=$ reliabilitas soal

$\mathrm{k}$ = banyaknya butir soal

$\sum \sigma_{b}{ }^{2}=$ jumlah varians butir

$\sigma_{t}^{2}=$ varians total

Kriteria koefisien korelasi reliabilitas tes :

$0,80<\mathrm{r}_{11} \leq 1,00$ : sangat tinggi

$0,60<\mathrm{r}_{11} \leq 0,80$ : tinggi

$0,40<\mathrm{r}_{11} \leq 0,60$ : sedang

$0,20<\mathrm{r}_{11} \leq 0,40$ : rendah

$0,00<r_{11} \leq 0,20$ : sangat rendah

Jadi kriteria yang dipakai jika reliabilitas soal tes pada kategori sedang dan tinggi.

e. Analisis tingkat kesukaran soal

Untuk menganalisis taraf kesukaran soal uraian maka digunakan rumus :

$$
T K=\frac{S_{A}+S_{B}}{n \operatorname{maks}}
$$

Jihad \& Haris (2012: 182)

Keterangan :

TK = angka indeks kesukaran
$\mathrm{S}_{\mathrm{A}}=$ jumlah skor kelompok atas

$\mathrm{S}_{\mathrm{B}}=$ jumlah skor kelompok bawah

$\mathrm{n}=$ jumlah siswa kelompok atas dan

kelompok bawah

maks = skor maksimum setiap butir

soal

Tabel 2 Kriteria kesukaran soal

\begin{tabular}{|c|c|}
\hline $\begin{array}{c}\text { Besarnya Indeks } \\
\text { Kesukaran Soal }\end{array}$ & Kriteria \\
\hline Kurang dari 0,30 & Sukar \\
\hline $0,30-0,70$ & Sedang \\
\hline Lebih dari 0,70 & Mudah \\
\hline
\end{tabular}

Sudijono (2009:372)

f. Analisis daya pembeda

Perhitungan daya pembeda tes uraian menggunakan rumus :

$$
D P=\frac{S_{A}-S_{B}}{\frac{1}{2} n \text { maks }}
$$

Jihad \& Haris (2012: 182)

Keterangan :

DP = angka day apembeda

$\mathrm{S}_{\mathrm{A}}=$ jumlah skor kelompok atas

$\mathrm{S}_{\mathrm{B}}=$ jumlah skor kelompok bawah

$\mathrm{n} \quad=$ jumlah siswa kelompok atas

dan kelompok bawah

maks $=$ skor maksimum setiap butir soal

Penelitian ini akan dihentikan jika kriteria keberhasilan tindakan telah tercapai. Adapun kriteria dan indikator keberhasilan tindakan adalah:

1. Valid (validitas soal oleh ahli materi)

Jika skor rata-rata validitas $\geq 2$ yang dikategorikan valid

2. Valid (validitas soal secara empiris)

a. Jika validitas soal $r_{\text {hitung }}>r_{\text {tabel }}$

b. Jika reliabilitas soal tes $0,40<$ $r_{11} \leq 1,00$

c. Jika tingkat kesukaran soal merata

d. Jika daya pembeda soal $\geq 50 \%$ dikategorikan baik

\section{HASIL DAN PEMBAHASAN}

\section{A. Hasil uji validitas}

1. Validitas logis

Pada uji validitas, peneliti menguji validitas logis dan validitas empiris. Validitas 
logis akan melihat kevalidan berdasarkan hasil penalaran validator. Pada validitas tiap butir soal, validator menguji 5 soal dengan 5 ragam soal, sehingga ada 25 soal yang diuji validitasnya. Uji validitas oleh validator dilakukan selama kurang lebih 2 minggu, dan validator langsung memberikan hasil vali

Validitasnya dengan beberapa saran perbaikan.Hasil validitas tiap butir soal oleh ketiga validator yaitu:

Tabel 3 Hasil validitas logis

\begin{tabular}{|l|c|c|c|c|}
\hline \multirow{2}{*}{ Validator } & \multicolumn{3}{|c|}{ Jumlah Soal } & Total \\
\cline { 2 - 5 } & Valid & $\begin{array}{c}\text { Kurang } \\
\text { Valid }\end{array}$ & $\begin{array}{c}\text { Tidak } \\
\text { Valid }\end{array}$ & \\
\hline $\begin{array}{l}\text { Validator } \\
1\end{array}$ & 15 & 10 & 0 & 25 \\
\hline $\begin{array}{l}\text { Validator } \\
2\end{array}$ & 25 & 0 & 0 & 25 \\
\hline $\begin{array}{l}\text { Validator } \\
3\end{array}$ & 22 & 3 & 0 & 25 \\
\hline
\end{tabular}

Berdasarkan hasil validitas logis tiap butir soal, semua soal bisa digunakan dengan syarat soal yang kurang valid harus diperbaiki. Setelah divalidasi setiap butir soal, validator memvalidasi soal secara keseluruhan dengan mengisi angket validasi. Berdasarkan hasil validitas logis, total skor pada lembar validitas soal oleh ahli materi yang diberikan kepada ketiga validator, yaitu:

Tabel 4 Hasil validitas logis setiap butir soal

\begin{tabular}{|l|c|c|c|}
\hline Validator & $\begin{array}{c}\text { Jumlah } \\
\text { skor }\end{array}$ & $\begin{array}{c}\text { Rata- } \\
\text { rata } \\
\text { skor }\end{array}$ & Kategori \\
\hline Validator 1 & 33 & 3,3 & $\begin{array}{c}\text { Sangat } \\
\text { Valid }\end{array}$ \\
\hline Validator 2 & 29 & 2,9 & Valid \\
\hline Validator 3 & 36 & 3,6 & $\begin{array}{c}\text { Sangat } \\
\text { Valid }\end{array}$ \\
\hline $\begin{array}{l}\text { Rata-rata } \\
\text { validator }\end{array}$ & ketiga & 3,26 & $\begin{array}{c}\text { Sangat } \\
\text { Valid }\end{array}$ \\
\hline
\end{tabular}

Rata-rata validitas soal oleh ketiga validator materi adalah 3,26 maka validitas soal oleh ahli materi secara keseluruhan dikatakan sangat valid.

\section{Validitas Empiris}

Setelah diuji validitas secara logis, peneliti menguji tes ke 2 kelas VIII pada SMP Negeri 01 Kabupaten Kepahiang. Tes ini diujikan ke kelas VIII F dan VIII H. Dari kedua pengujian ini akan dilihat validitas empiris soal tiap butir. Uji validitas butir soal menggunakan korelasi. Soal dikatakan valid jika nilai korelasi $\mathrm{r}>\mathrm{r}_{\text {tabel }}$, dengan taraf signifikan 5\%. Hasil yang didapatkan dari 25 butir ragam soal, ada 20 soal yang valid dan 5 soal yang tidak valid.

Tabel 5 Hasil validasi empiris setiap butir soal

\begin{tabular}{|l|c|c|c|}
\hline $\begin{array}{c}\text { Nomor } \\
\text { Soal }\end{array}$ & $\begin{array}{c}\text { Nilai r } \\
\text { hitung }\end{array}$ & $\begin{array}{c}\text { Nilai r } \\
\text { tabel }\end{array}$ & Kategori \\
\hline 1A & 0,87 & 0,497 & V \\
\hline 1B & 0,82 & 0,497 & V \\
\hline 1C & 0,82 & 0,497 & V \\
\hline 1D & 0,82 & 0,497 & V \\
\hline 1E & 0,49 & 0,497 & TV \\
\hline 2A & 0,90 & 0,497 & V \\
\hline 2B & 0,92 & 0,497 & V \\
\hline 2C & 0,85 & 0,497 & V \\
\hline 2D & 0,86 & 0,497 & V \\
\hline 2E & 0,80 & 0,497 & V \\
\hline 3A & 0,70 & 0,497 & V \\
\hline 3B & 0,91 & 0,497 & V \\
\hline 3C & 0,45 & 0,497 & TV \\
\hline 3D & 0,71 & 0,497 & V \\
\hline 3E & 0,68 & 0,497 & V \\
\hline 4A & 0,49 & 0,497 & TV \\
\hline 4B & 0,78 & 0,497 & V \\
\hline 4C & 0,84 & 0,497 & V \\
\hline 4D & 0,30 & 0,497 & TV \\
\hline 4E & 0,45 & 0,497 & TV \\
\hline 5A & 0,88 & 0,497 & V \\
\hline 5B & 0,74 & 0,497 & V \\
\hline 5C & 0,80 & 0,497 & V \\
\hline 5D & 0,85 & 0,497 & V \\
\hline 5E & 0,94 & 0,497 & V \\
\hline
\end{tabular}

Keterangan:

$\mathrm{V}=$ Valid

$\mathrm{TV}=$ Tidak Valid

3. Reliabilitas, Tingkat Kesukaran dan Daya Pembeda

a. Reliabilitas

Selain melihat validitas butir soal, agar menghasilkan soal yang baik, maka diuji 
reliable, daya pembeda dan tingkat kesukarannya. Untuk melihat reliable, daya pembeda dan tingkat kesukarannya dilihat dari hasil yang didapatkan setelas siswa mengerjakan tes pada uji valid empiri. Pada uji reliable, nilai reliabelnya adalah 0,7668 sehingga soal dikatakan reliable.

b. Tingkat Kesukaran

Pada uji tingkat kesukaran soal diperoleh:

Tabel 6 Hasil Tingkat Kesukaran

\begin{tabular}{|l|l|l|l|}
\hline \multirow{2}{*}{} & \multicolumn{4}{|l|}{ Kategori Tingkat Kesukaran } \\
\cline { 2 - 4 } & Sukar & Sedang & Mudah \\
\hline $\begin{array}{l}\text { Jumlah } \\
\text { Soal }\end{array}$ & 4 & 16 & 5 \\
\hline
\end{tabular}

Berdasarkan hasil uji tingkat kesukaran kategori tingkat kesukaran soal sudah merata.

\section{c. Daya Pembeda}

Pada uji daya pembeda, daya pembeda dibagi menjadi 4 kategori yaitu sangat baik, baik, kurang baik dan tidak baik. Hasil uji daya pembeda yang diperoleh yaitu:

\section{Tabel 7 Hasil Uji Daya Pembeda}

\begin{tabular}{|l|l|l|l|l|l|}
\hline $\begin{array}{l}\text { No. } \\
\text { Soal }\end{array}$ & $\begin{array}{c}\text { Variasi } \\
\text { A }\end{array}$ & Variasi B & $\begin{array}{c}\text { Variasi } \\
\text { C }\end{array}$ & Variasi D & $\begin{array}{c}\text { Variasi } \\
\text { E }\end{array}$ \\
\hline 1 & Baik & Sedang & Baik & Sedang & Jelek \\
\hline 2 & $\begin{array}{l}\text { Sanga } \\
\text { t Baik }\end{array}$ & Baik & Baik & Baik & Baik \\
\hline 3 & Jelek & Baik & Jelek & Sedang & Jelek \\
\hline 4 & Jelek & Jelek & Baik & Jelek & Jelek \\
\hline 5 & Baik & Baik & Baik & Baik & $\begin{array}{c}\text { Sangat } \\
\text { Baik }\end{array}$ \\
\hline
\end{tabular}

Dari hasil yang diperoleh, daya pembeda yang dikategorikan baik berjumlah 12 soal dan sangat baik berjumlah 2 soal, sehingga ada 14 soal yang dikategorikan baik ke atas. Jika banyak soal $\geq 50 \%$ dengan nilai DP $>0,40$ atau soal kategori baik ke atas $\geq 50 \%$ maka soal dikatakan memiliki daya pembeda yang baik. Dari hasil uji daya beda terhadap 25 soal, jumlah kategori daya pembeda yang $>0,40$ ada 14 soal sehingga ada $>50 \%$ yang daya pembedanya baik ke atas. Dengan demikian soal dapat dikatakan memiliki daya pembeda yang baik.Dengan demikian, berdasarkan hasil uji reliabilitas, tingkat kesukaran dan daya pembeda soal, soal yang digunakan untuk tes ini sudah baik.

\section{PENUTUP}

\section{Simpulan}

Validitas dari pengembangan tes secara logis diperoleh bahwa tes sangat valid, dan validitas dari pengembangan tes secara empiris, uji reliable, tingkat kesukaran dan daya pembeda diperoleh bahwa tes sudah baik untuk digunakan.

\section{Saran}

Adapun saran dalam penelitian ini adalah berdasarkan hasil uji coba tes, sebaiknya siswa lebih diajarkan lagi bagaimana cara membuktikan suatu rumus. Berdasarkan hasil uji coba tes, sebaiknya siswa lebih diajarkan lagi bagaimana penggunaan rumus secara prosedural. Ketika pelaksanaan tes, waktu pengambilan soal harus lebih efektif. Berdasarkan ragam soal yang dibuat, sebaiknya perbedaan antar ragam soal jangan hanya terfokus pada perbedaan angka-angkanya saja. Berdasarkan manfaat yang diperoleh dari penelitian ini, sebaiknya dikembangkan juga tes untuk materi-materi yang lain.

\section{DAFTAR PUSTAKA}

Arikunto, Suharsimi. 2010. Prosedur Penelitian Pendekatan Praktik. Jakarta: Rineka Cipta.

Hendriana, Heris dan Utari, Soemarmo. 2014. Penilaian Pembelajaran matematika. Bandung: Refika Aditama

Prastowo, Andi. 2013. Pengembangan Bahan Ajar Tematik. Yogyakarta: Diva Press.

Skemp, Richard R. 2002. Mathematics in the Primary School. London: Taylor Francis Group.

Sudjana. 1995. Metoda Statistika. Bandung: Tarsito. 